\title{
Texture Properties and Kinetic Parameters Associated to Carbon Materials Obtained from Sawdust of Algarroba Wood. 1. Application in Phenol Photodetoxification
}

\author{
Juan Matos*, Carol Nahas, Laura Rojas and Maibelin Rosales \\ Engineering of Materials and Nanotechnology Centre, Venezuelan Institute for Scientific Research (IVIC) 20632, \\ Caracas 1020-A, Venezuela
}

\begin{abstract}
Carbon materials were obtained by pyrolysis of the sawdust of Algarroba wood under $\mathrm{CO}_{2}$ or $\mathrm{N}_{2}$ atmospheres at temperatures from $200^{\circ} \mathrm{C}$ up to $900^{\circ} \mathrm{C}$. Carbon materials were characterized by surface and micropore areas, volume pore and mean pore diameter. An approach of the kinetic parameters (apparent constant-rates and activation energies) associated with the synthesis of these carbon materials is also presented. From the kinetic data of thermal degradation of Algarroba wood, three different pyrolysis zones were verified. First, an incipient carbonization between 200 up to $350^{\circ} \mathrm{C}$, second an extensive carbonization between 350 up to $600^{\circ} \mathrm{C}$, and a third step involving the pore formation at temperatures higher than $600^{\circ} \mathrm{C}$. As a target application of carbon materials, results of phenol adsorption and phenol photodegradation under UV-irradiation indicated the potential of carbon materials in presence of $\mathrm{TiO}_{2}$ for treatment of polluted waters.
\end{abstract}

Keywords: Thermal degradation, Carbon materials, Kinetics, Activation energy, Photocatalysis.

\section{INTRODUCTION}

Carbon-based materials as activated carbon (AC) have been extensively used as adsorbents and catalytic supports mainly due to the high surface area up to $3000 \mathrm{~m}^{2} \cdot \mathrm{g}^{-1}$ and a wide range of pore sizes [1]. Bituminous and lignocelluloses are the most common precursors employed as starting materials of activated carbons. Adsorption on AC depend on two fundamental characteristics, accessible internal surface area where adsorption takes place, and the presence of sites at which chemisorptions may occur. It is important to have a complete knowledge of the activated carbon properties because besides conventional applications, there is an increasing interest in develop AC for specifics needs. For example, $\mathrm{AC}$ has been employed in catalytic heterogeneous reactions such as hydrogasification [2,3], hydrodesulphurization [4, 5] and photocatalytic detoxification of waste waters [6-8], where its application is directly associated with textural and surface properties of carbon $[9,10]$. Also, an increasing interest in the influence of wood char [11] and wood-derived carbon-supported catalysts on the kinetics of methane decomposition [12] and dry methane reforming [13, 14] have been performed. Consequently, the study the kinetics parameters related with the synthesis of carbons from lignocelluloses precursor materials, such as sawdust from wood have receive some attention $[15,16]$. In addition, rigorous kinetic studies about the thermal decomposition of biomass materi-

*Address correspondence to this author at the Engineering of Materials and Nanotechnology Centre, Venezuelan Institute for Scientific Research, 20632, Caracas 1020-A, Venezuela; Tel: 00-58-212-5041166; Fax: 00-58212-5041166; E-mails: jmatos@ivic.gob.ve; jmatoslale@gmail.com als [17] and specifically about cellulose pyrolysis [18] have permitted to clarify the influence of gas evolution and the mechanisms related with the pyrolysis of lignocellulosic materials. In this sense, the main objective of this work is focussed to the synthesis and textual characterization of carbons materials obtained from the pyrolysis of sawdust of Algarroba wood under $\mathrm{CO}_{2}$ and $\mathrm{N}_{2}$ atmospheres. An additional study of the kinetics parameters and energies associated with the synthesis of these carbon materials is also included as an approach to insight into the possible mechanistic steps of the wood activation and to correlate these kinetics parameters with the textural properties. Finally, the influence of two carbons upon the phenol adsorption and on the photoefficiency of $\mathrm{TiO}_{2}$ in the phenol photo detoxification under UV-irradiation was studied as a targeted application.

\section{EXPERIMENTAL}

\subsection{Raw Material and Activated Carbon Characteriza- tion}

Sawdust from Algarroba (Hymenaea Courbaril) wood was employed. This wood was selected because in addition to low ash content it is a hard wood and therefore useful to some applications. For example, Laine et al. [19] has employed Algarroba wood to obtain activated carbons filters in the shape of monoliths with a high potential application in the treatment of polluted water as we showed in an early work [20]. Algarroba's sawdust was firstly crashed and sieved [21] before characterization and pyrolysis studies. The mean size of particles was $350 \mu \mathrm{m}$; however, an important proportion of particles with size lower than this was noticed that means that $\mathrm{AC}$ prepared will be on the micro particle solid classification. Tests of moisture at $120^{\circ} \mathrm{C}$ by $2 \mathrm{~h}$ 


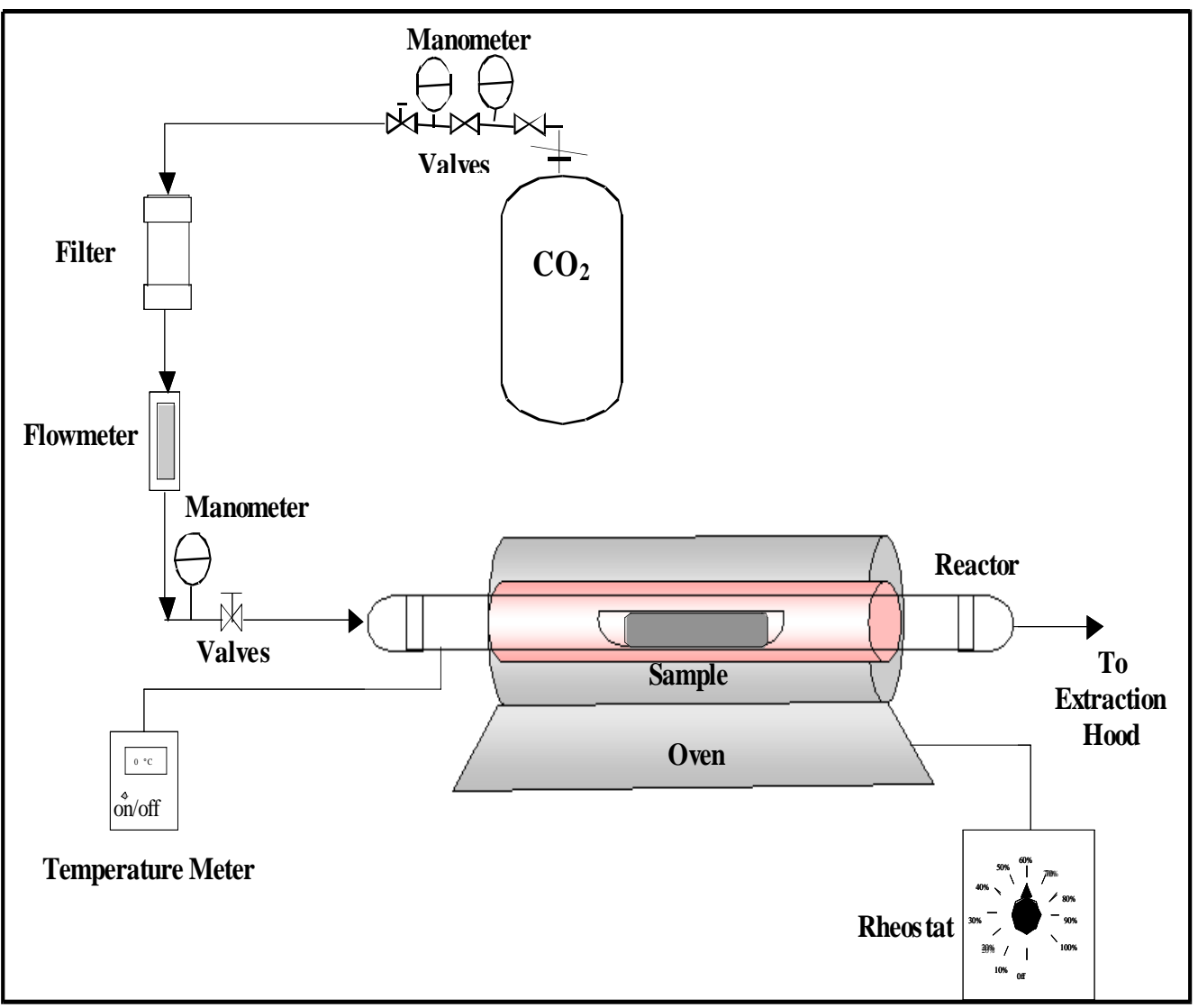

Fig. (1). Scheme of activation set-up.

[22], ash at $550^{\circ} \mathrm{C}$ by $14 \mathrm{~h}$ [23] and volatiles at $850^{\circ} \mathrm{C}$ by $7 \mathrm{~min}$ [24] were also performed following ASTM standards [22-24]. Bulk density was also estimated by geometrical filled method with sieved microparticles of $350 \mu \mathrm{m}$. Identification and quantification of the elements $\mathrm{Al}, \mathrm{B}, \mathrm{Ba}, \mathrm{Cr}, \mathrm{Cu}$, $\mathrm{Mg}, \mathrm{Mn}, \mathrm{Na}, \mathrm{Ni}, \mathrm{P}, \mathrm{Si}, \mathrm{Sr}, \mathrm{Zn}$ was performed in an inductively-coupled plasma atomic emission spectrophotometer (ICP-AES) from Varian (model 730ES-Axial, series EL07114070). Quantification of these elements was performed by using a multielemental standard from High Purity (E.P.A. 2007) at five different concentrations. The determination of $\mathrm{Ca}$, Fe and $\mathrm{K}$ was performed in an atomic absorption (AA) spectrophotometer from Perkin Elmer (model Analyst 400, series 201S3090705). In these cases, quantification was performed by using calibration curves with five different concentrations from standards FisherScientific (for $\mathrm{Fe}$ ) and Ricca Chemical Company (for $\mathrm{Ca}$ and $\mathrm{K}$ ). Other elements such as As, Be, Cs, Cd, Co, Ge, In, La, Mo, Pb, Sb, $\mathrm{Sc}, \mathrm{Se}, \mathrm{Sn}, \mathrm{Ti}, \mathrm{Tl}$, and V, were also explored but they were not detected. Analysis was done by triplicate for the samples and ashes and the reproducibility of results being better than $99 \%$. Textural characterization was performed by $\mathrm{N}_{2}$ adsorption-desorption isotherms at $77 \mathrm{~K}$. The full isotherms in the range of $4 \times 10^{-3}$ to $84 \mathrm{kPa}$ were measured in a Micromeritics ASAP-2010. Equivalent surface area, micropore area and volume, and pore diameters were obtained by BrunauerEmmet-Teller (BET), Harkins-Jura (HJ) and HorvathKawazoe (HK) methods, respectively [25-27]. HJ and HK were employed because they provide an accounting for the adsorbed layer on pore walls when calculating pore size distribution and because they are very useful when different types of pores are involved. Therefore, HJ and HK methods are proper for the present case because carbon materials can contain slits and spherical pores.

\subsection{Thermal Degradation of Sawdust}

Pyrolysis was carried out at nearly constant atmospheric pressure $(100 \mathrm{kPa})$ inside a tubular kiln (HM 16, Heraeus GmBH Germany). Fig. (1) shows a schematic representation of the equipment used in the present work where reactor employed was made of stainless steel or Pyrex glass depending of final pyrolysis temperature. Final temperatures of oven were calibrated with standard deviation less than $2 \%$ by using a rheostat (Heraeus). Isothermal conditions were revised and oven remains its final temperature during all kinetic studies. Samples of $3 g$ of sieved sawdust were placed in the oven at ambient temperature. Samples were pyrolyzed under $\mathrm{CO}_{2}$ or $\mathrm{N}_{2}$ gas flows (100mL.min ${ }^{-1}$ ) from 20 up to the final temperatures between $200^{\circ} \mathrm{C}$ up to $900^{\circ} \mathrm{C}$ at constant heating rate $\left(10^{\circ} \mathrm{C} / \mathrm{min}\right)$. Temperature was kept constant for different holding times $(0,1,2 \mathrm{~h})$ after achieve the final selected temperature. From a pre-industrial scale point of view, the controlled pyrolysis of lignocellulosic precursors as sawdust from wood is the most single and cheaper methodology to obtain carbon material. The selection of the temperatures ranges studied in the present work was made to compare against previous results from Laine et al. [4,5,19] and from our own group $[9,10]$. Different wood samples were used for 

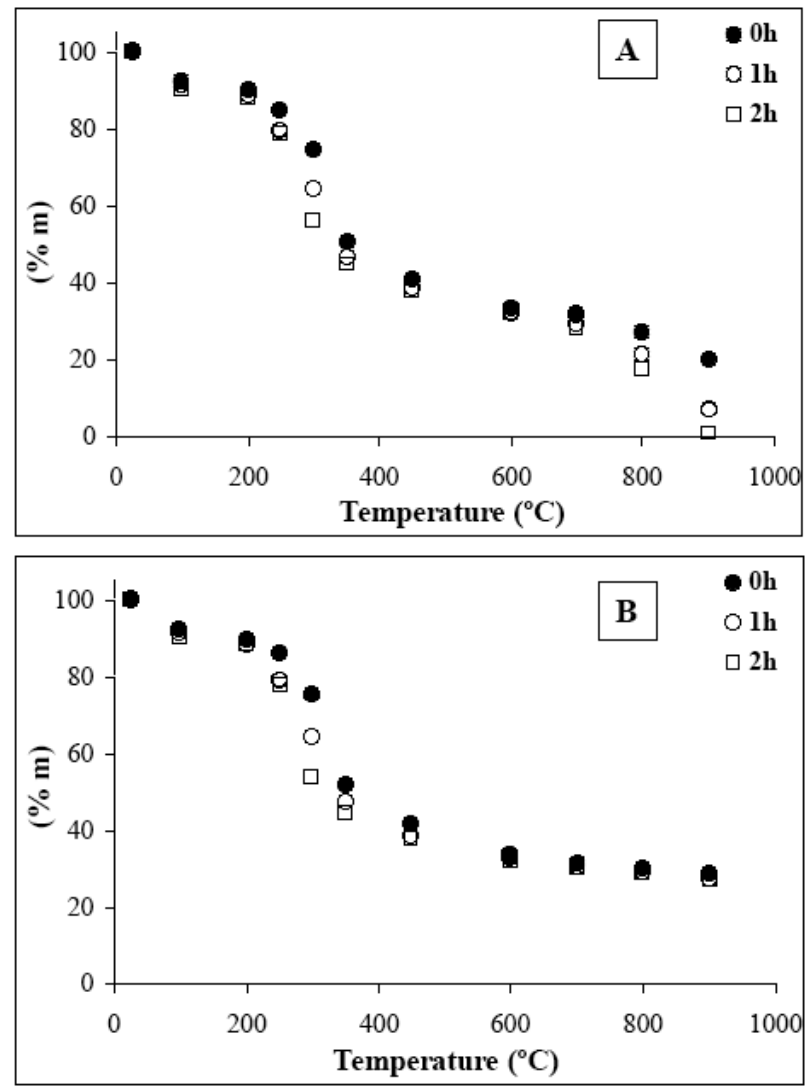

Fig. (2). Mass remaining (\%m) after pyrolysis of Algarroba wood. (A): Under $\mathrm{CO}_{2}$ flow. (B): Under $\mathrm{N}_{2}$ flow.

each experiment and changes between initial $\left(\mathrm{m}_{\mathrm{o}}\right)$ and mass remaining $\left(\mathrm{m}_{\mathrm{t}}\right)$ after these times were verified. From the mass remaining data of pyrolysis as function of the gas atmosphere, the temperature and the time of reaction, the apparent constant rates and activation energies in three different pyrolysis zones were estimated as follows.

\subsection{Estimation of Kinetic Parameters}

The kinetic of thermal decomposition of the wood was studied assuming a first-order reaction mechanism as suggested the mass remaining trends (Fig. 2) obtained after the thermal degradation of the wood. This will be discussed in the result and discussion section. In this sense, first-order apparent constants $\left(\mathrm{k}_{\mathrm{ap}, \mathrm{Ti}}\right)$ were estimated as a function of temperature from the linear regression of equation (1), giving equation (2):

$$
\begin{aligned}
& \mathrm{d}(\% \mathrm{~m})=-\mathrm{k}_{\mathrm{ap}, \mathrm{Ti}} \cdot \% \mathrm{~m} \cdot \mathrm{dt} \\
& \operatorname{Ln}\left(\% \mathrm{~m}_{\mathrm{o}} / \% \mathrm{~m}_{\mathrm{t}}\right)=\mathrm{k}_{\mathrm{ap}, \mathrm{Ti}} \cdot \mathrm{t}
\end{aligned}
$$

where $\% \mathrm{~m}_{\mathrm{o}}$ is the mass remaining at zero reaction time, $\% \mathrm{~m}_{\mathrm{t}}$ is the mass remaining after 1 and $2 \mathrm{~h}$ reaction, $\mathrm{t}$ is the reaction time and $\mathrm{k}_{\mathrm{ap}, \mathrm{Ti}}$ is the first-order apparent rate constant at the specific temperature $\mathrm{T}_{\mathrm{i}}$. Activation energies associated to different pyrolysis zones in the synthesis of carbon materials were estimated from the Arrhenius kinetic formulation [17]:

$$
\begin{aligned}
\mathrm{k}_{\mathrm{ap}, \mathrm{Ti}} & =\mathrm{A} \cdot \exp (-\mathrm{Ea} / \mathrm{R} \cdot \mathrm{T}) \\
\operatorname{Ln}\left(\mathrm{k}_{\mathrm{ap}, \mathrm{Ti}}\right) & =\operatorname{Ln}(\mathrm{A})-\left(\mathrm{E}_{\mathrm{a}} / \mathrm{R} \cdot \mathrm{T}\right)
\end{aligned}
$$

where $\mathrm{E}_{\mathrm{a}}$ and $\mathrm{A}$ in equations 3 and 4 correspond to the activation energy and to the frequency factor, respectively and $R$ corresponds to the gas constant. A is also known as the preexponential Arrhenius factor and is commonly related with the probability of reaction [28]. In the present study, we found that in the pyrolysis zone between $300-600^{\circ} \mathrm{C}$, the higher the temperature the lower the first-order apparent rate constant. Therefore, we used a first-order differential equation (Eq. 5), as an approximation to estimate the activation energy by means of the linear transformation of equation 6 .

$$
\begin{aligned}
& \mathrm{dk}_{\mathrm{ap}, \mathrm{Ti}}=\left(-\mathrm{k}_{\mathrm{ap}, \mathrm{Ti}} \cdot \mathrm{R} \cdot \mathrm{dT}\right) \\
& \operatorname{Ln}\left(\mathrm{k}_{\mathrm{ap}, \mathrm{To}} / \mathrm{k}_{\mathrm{ap}, \mathrm{Ti}}\right)=\left(1 / \mathrm{E}_{\mathrm{a}}\right) \mathrm{R} \cdot \mathrm{Ti}
\end{aligned}
$$

\subsection{Phenol Photodetoxification}

Phenol was purchased from Aldrich. The photocatalyst was $\mathrm{TiO}_{2}$ Degussa P25, mainly anatase (ca. 70\%) under the shape of non-porous polyhedral particles of ca. $30 \mathrm{~nm}$ mean size with a surface area of $50 \mathrm{~m}^{2} / \mathrm{g}$. Activated carbons prepared under $\mathrm{CO}_{2}$ and $\mathrm{N}_{2}$ flow at $800^{\circ} \mathrm{C}$ and $1 \mathrm{~h}$ were selected for the study because they showed the highest surface areas (discussed below). These samples were denoted: $\mathrm{TiO}_{2}-\mathrm{AC}_{\mathrm{CO} 2}$ and $\mathrm{TiO}_{2}-\mathrm{AC}_{\mathrm{N} 2}$. The experimental set-up has been described before $[6,7]$ but it can be summarized as follows. The batch photoreactor was a cylindrical flask made of Pyrex of ca. $100 \mathrm{ml}$ with a bottom optical window of ca. $4 \mathrm{~cm}$ diameter and was open to air. Irradiation was provided by a high pressure mercury lamp (Phillips HPK $125 \mathrm{~W}$ ) and was filtered by a circulating-water cell (thickness $2.2 \mathrm{~cm}$ ) equipped with a $340 \mathrm{~nm}$ cut-off filter (Corning 0.52). The water cell was used to remove all the IR beams, thus preventing any heating of the suspension, especially in the presence of black activated carbon. The cut-off filter, although decreasing the overall UV-light power available, enables one to eliminate any photochemical side reaction. Millipore disks $(0.45 \mu \mathrm{m})$ were used to remove particulate matter before HPLC analysis. The HPLC system comprised a LDC/Milton Roy Constametric 3200 isocratic pump and a Waters 486 tunable absorbance detector (Millipore) adjusted at $270 \mathrm{~nm}$ for the detection of phenol. The quantity of $50 \mathrm{mg}$ of titania was chosen since in our conditions there is a full absorption of the UV light entering the photoreactor and because it has shown a optimum of composition in the photodegradation of phenol [6]. The quantity of $10 \mathrm{mg} \mathrm{AC}$ was chosen to ensure a good adsorption of phenol related to the high surface area of $\mathrm{AC}$ without disturbing the UV absorption by titania nor phenol adsorption on it [6]. Samples of the suspension were removed at regular intervals for analysis and from the linear regression of the kinetic data of phenol disappearance as a function of reaction time $\operatorname{Ln}\left(\mathrm{C}_{\mathrm{o}} / \mathrm{C}_{\mathrm{t}}\right)=\mathrm{f}(\mathrm{t})$, the first-order apparent rateconstans $\left(\mathrm{k}_{\text {app-phenol }}\right)$ were obtained to compare the photoefficiency of the $\mathrm{TiO}_{2}$-AC against $\mathrm{TiO}_{2}$ alone. Further details can be verified elsewhere [6].

\section{RESULTS AND DISCUSSION}

\subsection{Raw Material Characterization}

Results of wood characterization are shown in Table 1. It can be inferred that moisture (about 10\%wt water content) would not affect activation processes. Volatile high content (about 72\%wt) indicates that Algarroba's samples of the 
Table 1. Characterization of Hymenaea Courbaril Wood

\begin{tabular}{|c|c|}
\hline Moisture (wt\%) & $9.8 \pm 0.4$ \\
\hline Ash (wt\%) & $1.30 \pm 0.04$ \\
\hline Volatiles (wt\%) & $72.1 \pm 0.7$ \\
\hline Fixed carbon (wt\%) & $16.8 \pm 1,3$ \\
\hline Apparent Density $\left(\mathrm{g} / \mathrm{cm}^{3}\right)$ & $0.89 \pm 0.03$ \\
\hline
\end{tabular}

present work are from a young wood and therefore, low yields should be obtained after pyrolysis. A low metal content (about 1.3\%wt) was also detected in the carbonaceous precursor. Table 2 shows a summary of the atomic absorption (AA) analysis obtained from ashes of Algarroba. In general, low metal content of about $1.3 \mathrm{wt} \%$ were detected in the composition of the wood suggesting that carbon materials would have a high purity. These metals were mainly alkaline ( $\mathrm{Na}$ and $\mathrm{K}$ ), and alkaline-earth $(\mathrm{Ca}, \mathrm{Mg}, \mathrm{Ba}$ and $\mathrm{Sr}$ ). Also, it must be note an important quantity of phosphor (ca. $0.7 \%$ wt). Laine et al. [19] have reported that $\mathrm{P}$ found in carbons obtained from Algarroba is commonly structured in the shape of cyclic or linear polyphosphates $\left[\left(\mathrm{P}_{\mathrm{n}} \mathrm{O}_{3 n}\right)\right] n-$ and $\left[\left(\mathrm{P}_{\mathrm{n}} \mathrm{O}_{3 \mathrm{n}+1}\right)\right](\mathrm{n}+2)-$, respectively, that can be coordinated to the carbon sheets indicating a strong interaction between phosphates anions and carbon atoms. Low content of amphoteric elements ( $\mathrm{Al}$ and $\mathrm{Si})$ and first row transition metals $(\mathrm{Cr}$, $\mathrm{Cu}, \mathrm{Fe}, \mathrm{Ni}, \mathrm{Zn}$ and $\mathrm{Mn}$ ) were also detected.

\subsection{Thermal Degradation of Wood}

In preliminary studies (not shown) from $300^{\circ} \mathrm{C}$ up to $450^{\circ} \mathrm{C}$ under $\mathrm{CO}_{2}$ flow, besides $10^{\circ} \mathrm{C} / \mathrm{min}$ we employed $5^{\circ} \mathrm{C} / \mathrm{min}$ but no representative changes were detected on mass remaining. For that reason we selected $10^{\circ} \mathrm{C} / \mathrm{min}$ in order to compare the present yields against those reported previously by Laine et al. [19] for monolithic carbons at low temperature and by our group for activated carbons prepared at high temperatures [20]. The mass remaining $(\% \mathrm{~m})$ after thermal degradation under $\mathrm{CO}_{2}$ or $\mathrm{N}_{2}$ flow are show in Fig. (2A and 2B), respectively. This figure also includes the moisture lost by the heating up to $120^{\circ} \mathrm{C}$. In both cases, it can be noted that thermal decomposition started about $200^{\circ} \mathrm{C}$ in agreeing with previous works of lignocelluloses materials decomposition [15, 16, 29]. Fig. (2) shows three different thermal degradation zones as a function of temperature. The first zone can be distinguish between $200-300^{\circ} \mathrm{C}$, the second one between $350-600^{\circ} \mathrm{C}$ and the last one between $600-900^{\circ} \mathrm{C}$. For the case of thermal degradation under $\mathrm{CO}_{2}$ atmosphere, it can be note from Fig. (2A) that the higher the activation temperature and reaction time the lower the mass remaining. For the case of pyrolysis under $\mathrm{N}_{2}$ flow, Fig. (2B) shows a similar behaviour up to $700^{\circ} \mathrm{C}$ where the mass remaining $(\% \mathrm{~m})$ is practically constant at higher temperatures than $700^{\circ} \mathrm{C}$. The different trends in the mass remaining as a function of gaseous atmospheres was expected because carbonized wood reacts efficiently with $\mathrm{CO}_{2}$ at temperature higher than $690^{\circ} \mathrm{C}$ by the well-known Boudouart reaction: [30]

Table 2. Atomic Absorption Analysis of Ashes from Algarroba Wood

\begin{tabular}{|c|c|c|c|}
\hline Element & $\begin{array}{c}\text { Concentration in Ashes } \\
(\mathrm{mg} / \mathrm{L})\end{array}$ & $\begin{array}{l}\text { Proportion } \\
\quad(\%)\end{array}$ & $\begin{array}{c}\text { Wood Composition } \\
(w t \%)\end{array}$ \\
\hline $\mathrm{Al}$ & 18.31 & 1.05 & 0.0136 \\
\hline $\mathrm{Ba}$ & 0.51 & 0.03 & 0.0004 \\
\hline B & 1.83 & 0.10 & 0.0014 \\
\hline $\mathrm{Cr}$ & 0.17 & 0.01 & 0.0001 \\
\hline $\mathrm{Cu}$ & 1.58 & 0.09 & 0.0012 \\
\hline $\mathrm{Fe}$ & 86.46 & 4.95 & 0.0653 \\
\hline $\mathrm{Mg}$ & 112.05 & 6.41 & 0.0846 \\
\hline $\mathrm{P}$ & 934.57 & 53.47 & 0.7057 \\
\hline K & 42.58 & 2.44 & 0.0322 \\
\hline $\mathrm{Si}$ & 0.82 & 0.05 & 0.0006 \\
\hline $\mathrm{Na}$ & 2.61 & 0.15 & 0.0020 \\
\hline $\mathrm{Sr}$ & 2.69 & 0.15 & 0.0020 \\
\hline $\mathrm{Zn}$ & 4.66 & 0.27 & 0.0035 \\
\hline Total & 1747.91 & 100.00 & 1.30 \\
\hline
\end{tabular}


Table 3. B.E.T Surface Area of Carbon Materials Prepared by Pyrolysis Under $\mathrm{CO}_{2}$ or $\mathrm{N}_{2}$ Flow

\begin{tabular}{|c|c|c|c|c|}
\hline & \multicolumn{2}{|c|}{ Zero Time Residence } & \multicolumn{2}{c|}{ 1h Residence } \\
\hline Temp. $\left({ }^{\circ} \mathbf{C}\right)$ & $\mathbf{S}_{\text {BET }} \mathbf{C O}_{\mathbf{2}}\left(\mathbf{m}^{2} / \mathbf{g}\right)$ & $\mathbf{S}_{\text {BET }} \mathbf{N}_{\mathbf{2}}\left(\mathbf{m}^{2} / \mathbf{g}\right)$ & $\mathbf{S}_{\text {BET }} \mathbf{C O}_{\mathbf{2}}\left(\mathbf{m}^{2} / \mathbf{g}\right)$ & $\mathbf{S}_{\text {BET }} \mathbf{N}_{\mathbf{2}}\left(\mathbf{m}^{2} / \mathbf{g}\right)$ \\
\hline \hline 350 & $45 \pm 3$ & $7 \pm 1$ & $92 \pm 1$ & $34 \pm 1$ \\
\hline 450 & $171 \pm 3$ & $23 \pm 1$ & $350 \pm 7$ & $220 \pm 6$ \\
\hline 600 & $288 \pm 6$ & $310 \pm 8$ & $870 \pm 17$ & $527 \pm 2$ \\
\hline 700 & $330 \pm 7$ & $328 \pm 6$ & $1038 \pm 28$ & $549 \pm 2$ \\
\hline 800 & $426 \pm 19$ & $372 \pm 7$ & $7167 \pm 31$ & $471 \pm 12$ \\
\hline 900 & $534 \pm 10$ & $387 \pm 8$ & & \\
\hline
\end{tabular}

Table 4. Micropore Area ( $\mu$ pore $_{\text {area }}$ ), Micropore Volume ( $\mu$ pore volume$)$ and Mean width of Pore $\left(\mathrm{W}_{\text {pore }}\right)$ of Carbon Materials Prepared by Pyrolysis Under $\mathrm{CO}_{2}$ or $\mathrm{N}_{2}$ Flow after $1 \mathrm{~h}$ Reaction

\begin{tabular}{|c|c|c|c|c|c|c|}
\hline & $\mathrm{CO}_{2}$ Flow & $\mathrm{CO}_{2}$ Flow & $\mathrm{CO}_{2}$ Flow & $\mathbf{N}_{2}$ Flow & $\mathbf{N}_{2}$ Flow & $\mathbf{N}_{2}$ Flow \\
\hline $\mathbf{T}\left({ }^{\circ} \mathbf{C}\right)$ & $\mu$ pore $_{\text {area }}\left(\mathrm{m}^{2} / \mathbf{g}\right)^{\mathbf{a}}$ & $\begin{array}{c}\text { بpore }_{\text {volume }} \\
\left(\mathrm{cm}^{3} / \mathrm{g}\right)^{\mathrm{b}}\end{array}$ & $\begin{array}{c}\mathbf{W}_{\text {pore }} \\
{ }_{(\AA)} \mathbf{c}^{\mathbf{c}}\end{array}$ & $\mu$ pore $_{\text {area }}\left(\mathbf{m}^{2} / \mathbf{g}\right)^{a^{a}}$ & $\begin{array}{c}\mu \text { pore }_{\text {volume }} \\
\left(\mathrm{cm}^{3} / \mathrm{g}\right)^{\mathrm{b}}\end{array}$ & $\begin{array}{l}\mathbf{W}_{\text {pore }} \\
{ }_{(\AA)} \mathbf{c}^{\mathbf{c}}\end{array}$ \\
\hline $350^{\circ} \mathrm{C}$ & $--^{\mathrm{d}}$ & $--^{d}$ & 1815 & $--^{\mathrm{d}}$ & $--^{\mathrm{d}}$ & 922 \\
\hline $450^{\circ} \mathrm{C}$ & 327 & 0.010 & 54.5 & 202 & 0.101 & 43.3 \\
\hline $600^{\circ} \mathrm{C}$ & 624 & 0.241 & 20.6 & 449 & 0.172 & 16.3 \\
\hline $700^{\circ} \mathrm{C}$ & 892 & 0.411 & 20.0 & 494 & 0.188 & 15.8 \\
\hline $800^{\circ} \mathrm{C}$ & 1003 & 0.462 & 18.6 & 515 & 0.195 & 15.8 \\
\hline $900^{\circ} \mathrm{C}$ & 646 & 0.573 & 6.72 & 455 & 0.223 & 5.33 \\
\hline
\end{tabular}

${ }_{\mathrm{a}, \mathrm{b}}$ Obtained by HJ method. ${ }^{\mathrm{c} O b t a i n e d ~ b y ~ H K}$ method. ${ }^{\mathrm{d}}$ Not detected

$$
\mathrm{C}+\mathrm{CO}_{2} \rightarrow 2 \mathrm{CO}
$$

which is a bimolecular process. By contrast, under $\mathrm{N}_{2}$ atmosphere the unimolecular thermal decomposition of wood occurs from low temperatures as $200^{\circ} \mathrm{C}$ up to $700^{\circ} \mathrm{C}$. At higher temperatures than $700^{\circ} \mathrm{C}$ and under inert atmospheres, the aromatization of carbon atoms has been previously reported by us and other authors [31-35]. This proposal is in agreement with the constancy of the mass remaining at temperatures higher than $700^{\circ} \mathrm{C}$ (Fig. 2B).

\subsection{Texture of AC}

A summary of BET surface areas $\left(\mathrm{S}_{\mathrm{BET}}\right)$, micropore area $\left(\mu\right.$ pore $\left._{\text {area }}\right)$, micropore volume $\left(\mu\right.$ pore $\left._{\text {volume }}\right)$ and mean pore width $\left(\mathrm{W}_{\text {pore }}\right)$ corresponding to carbon materials prepared under $\mathrm{CO}_{2}$ and $\mathrm{N}_{2}$ atmospheres are compiled in Table $\mathbf{3}$ and 4. For the samples heated up to final temperature and with zero reaction time, it can be seen from Table 3 that the higher the temperatures of thermal degradation of wood the higher the $\mathrm{S}_{\mathrm{BET}}$. This can be associated to a pore opening by the thermal effect $[31,35]$. By contrast, for the case of $1 \mathrm{~h}$ reaction time, maxima values in BET surface area were obtained at $800^{\circ} \mathrm{C}$ for both atmospheres. This trend has been previously reported by some of us in the activation of sac- charose under $\mathrm{CO}_{2}$ and $\mathrm{N}_{2}$ flow [31] and can be observed in Fig. (3). In the same direction as above, the higher the time of thermal degradation of wood the higher the $\mathrm{S}_{\mathrm{BET}}$. This effect is consequence of a pore opening by the evolution of gas species for the case of the pyrolysis under $\mathrm{N}_{2}$ flow or by an enhance interaction between the carbon layers with $\mathrm{CO}_{2}$ induced by the thermal effect $[31,35]$. In consequence, BET surface area of carbon materials prepared by $1 \mathrm{~h}$ of thermal treatment were higher than those prepared only heating up to the final temperature. For this reason, carbons prepared by $1 \mathrm{~h}$ of thermal degradation were selected for the porosimetry study and results are showed in Table 4. In general, the higher the temperature of degradation of the wood the higher the micropores volume $\left(\mu\right.$ pore $\left.{ }_{\text {volume}}\right)$ of carbons prepared. However, for the micropore area ( $\mu$ pore ${ }_{\text {area }}$ ) parameter, a maxima value is reached at $800^{\circ} \mathrm{C}$ in agreeing with $\mathrm{S}_{\mathrm{BET}}$ (Table 3) and in most of cases, the microporous area contributes with about $90 \%$ of the total surface area. It can be seen in Table 4 that the higher the final temperature of thermal degradation the lower the mean width of pore $\left(\mathrm{W}_{\text {pore }}\right)$. For temperatures of 350 and $450^{\circ} \mathrm{C}$ macro- and mesoporous carbons were obtained respectively, whereas between 600 and $800^{\circ} \mathrm{C}$ microporous materials were obtained. Finally, ultramicroporous carbon materials were obtained at $900^{\circ} \mathrm{C}$ with the lowest mean width of pore of about $6.7 \AA$ and $5.3 \AA$, 


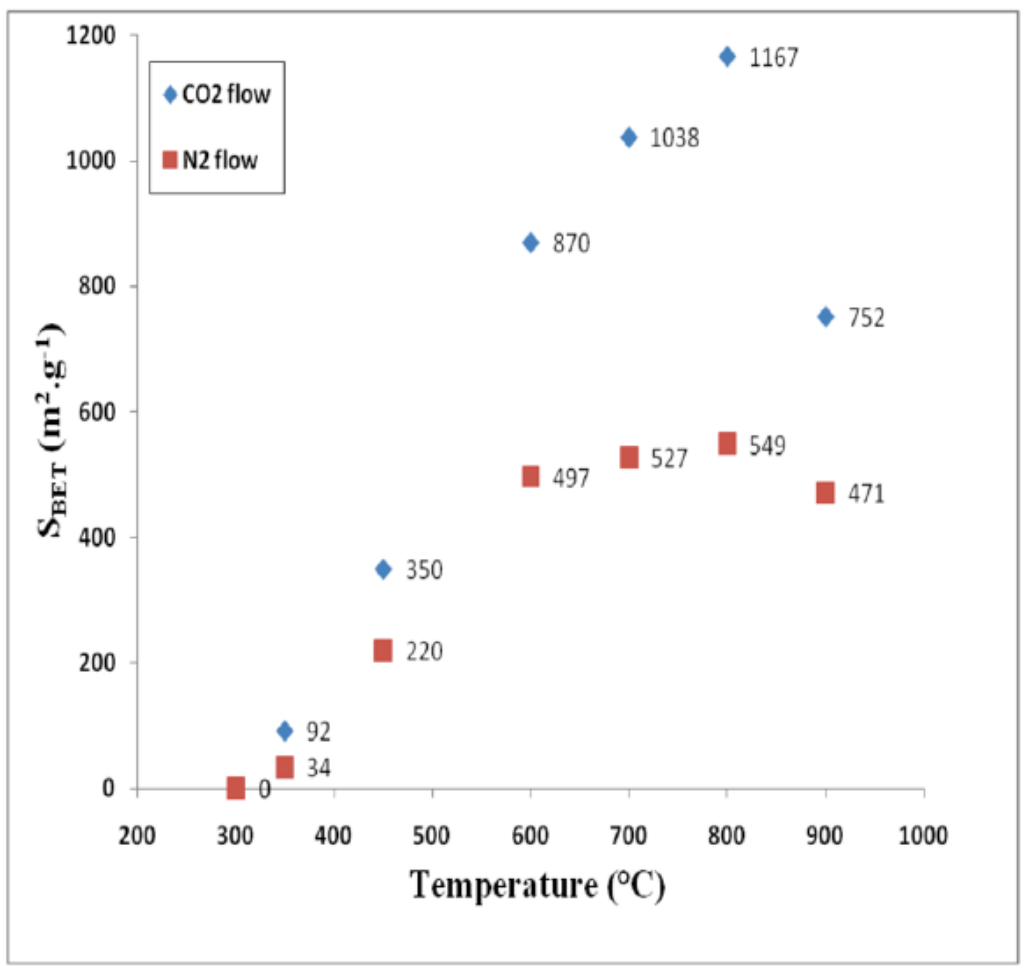

Fig. (3). Trend of BET surface area as a function of temperature for $1 \mathrm{~h}$ activation under $\mathrm{CO}_{2}$ flow or $1 \mathrm{~h}$ of pyrolysis under $\mathrm{N}_{2}$ flow.

Table 5. Linear Regression of Kinetic Data from Fig. (2).

\begin{tabular}{|c|c|c|c|c|}
\hline Temperature $\left({ }^{\circ} \mathbf{C}\right)$ & $\begin{array}{c}\mathrm{CO}_{2} \text { Flow } \\
\mathbf{k}_{\mathrm{ap}}\left(\min ^{-1}\right)\end{array}$ & $\mathbf{F}^{\mathrm{a}}$ & $\begin{array}{c}\mathbf{N}_{2} \text { Flow } \\
\mathbf{k}_{\mathrm{ap}}\left(\mathbf{m i n}^{-1}\right)\end{array}$ & $\mathbf{F}^{\mathrm{a}}$ \\
\hline 200 & $2.294 \times 10^{-4}$ & 0.99 & $1.420 \times 10^{-4}$ & 0.80 \\
\hline 250 & $6.031 \times 10^{-4}$ & 0.85 & $8.372 \times 10^{-4}$ & 0.87 \\
\hline 300 & $23.38 \times 10^{-4}$ & 0.99 & $27.73 \times 10^{-4}$ & 0.99 \\
\hline 450 & $6.714 \times 10^{-4}$ & 0.90 & $7.609 \times 10^{-4}$ & 0.90 \\
\hline 600 & $3.797 \times 10^{-4}$ & 0.87 & $4.563 \times 10^{-4}$ & 0.98 \\
\hline 700 & $9.835 \times 10^{-4}$ & 0.90 & $3.429 \times 10^{-4}$ & 0.81 \\
\hline 800 & $36.95 \times 10^{-4}$ & 0.99 & $4.073 \times 10^{-4}$ & 1.00 \\
\hline
\end{tabular}

${ }^{\mathrm{a}} \mathrm{F}$ corresponds to the square factor of linear regression

under $\mathrm{CO}_{2}$ and $\mathrm{N}_{2}$ atmospheres, respectively. It is important to remark that in all temperatures, the mean width of pores were lower for the carbons obtained under $\mathrm{N}_{2}$ flow than those obtained under $\mathrm{CO}_{2}$ atmosphere. For example, at $350^{\circ} \mathrm{C}$, the mean width of carbon obtained under $\mathrm{N}_{2}$ flow was about the half than that obtained under $\mathrm{CO}_{2}$ flow, $922 \AA$ against $1815 \AA$, respectively. This trend was the same at $450^{\circ} \mathrm{C}$ where mesoporous carbon materials were obtained, $43 \AA$ against $54 \AA$, under $\mathrm{N}_{2}$ and $\mathrm{CO}_{2}$ atmospheres, respectively, and also the same in the range $\left(600-900^{\circ} \mathrm{C}\right)$ where carbons obtained were microporous. In short, these results suggest that pore opening is influence by reaction atmos- phere and this fact could be related with the activation energies associated with the synthesis of carbon materials discussed as follows.

\subsection{Kinetic Parameters}

We have pointed out in the experimental section that the kinetic of thermal decomposition of sawdust of Algarroba wood was studied assuming a first-order reaction mechanism. In this sense, first-order apparent constants $\left(\mathrm{k}_{\mathrm{ap}, \mathrm{Ti}}\right)$ were estimated as a function of temperature by equations 1 and 2 . $\mathrm{k}_{\mathrm{ap}, \mathrm{Ti}}$ values in Table 5 and mass remaining in Fig. (2), sug- 
Table 6. Arrhenius Parameters as Function of Gas Atmosphere and Pyrolysis Zones

\begin{tabular}{|c|c|c|c|c|}
\hline & \multicolumn{2}{|c|}{ CO $_{2}$ flow } & \multicolumn{2}{c|}{ N $_{\mathbf{2}}$ Flow } \\
\hline $\begin{array}{c}\text { Temperature } \\
\left({ }^{\circ} \mathbf{C}\right)\end{array}$ & $\begin{array}{c}\text { A } \\
\left(\mathbf{m i n}^{-1}\right)\end{array}$ & $\begin{array}{c}\mathbf{E}_{\mathbf{a}} \\
\left(\mathbf{k c a l . m o l}^{-1}\right)\end{array}$ & $\begin{array}{c}\text { A } \\
\left(\mathbf{m i n}^{-1}\right)\end{array}$ & $\mathbf{E}_{\mathbf{a}}$ \\
\hline $200-300$ & 112.5 & 12.4 & 3908.1 & 16.1 \\
\hline \hline $350-600$ & 23.54 & 0.09 & 33.73 & 0.06 \\
\hline $600-900$ & 2460 & 27.8 & 0.03 & 8.84 \\
\hline
\end{tabular}

gest that mechanism involved in the synthesis of the present carbon materials would be composed by 3 different pyrolysis zones. Firstly, an incipient carbonization process take place at low temperature $\left(200-300^{\circ} \mathrm{C}\right)$ by consequence of carbohydrate dehydration $\left(\mathrm{CH}_{2} \mathrm{O} \rightarrow \mathrm{C}+\mathrm{H}_{2} \mathrm{O}\right)$ to produce macroporous materials. Second, in a middle pyrolysis zone at temperatures between 350 up to $600^{\circ} \mathrm{C}$, an extensive carbonization of sawdust take place to produce mesoporous materials. The third pyrolysis zone is located at high temperatures $(\mathrm{T}>$ $600^{\circ} \mathrm{C}$ ) where the microporous formation take place by a rearrangement of carbon layers under $\mathrm{N}_{2}$ atmosphere or by gasification according to the Boudouart reaction discussed above [30]. This step would be influenced by some of the wood composition elements such as $\mathrm{K}, \mathrm{Mg}$ and $\mathrm{Ca}$, because they could act as catalysts in the gasification reaction [33, 34]. It can be seen from Table 5 that at the low pyrolysis zone $\left(200-300^{\circ} \mathrm{C}\right)$ and at the middle pyrolysis zone $(350-$ $\left.600^{\circ}\right), \mathrm{k}_{\mathrm{ap}, \mathrm{Ti}}$ values obtained under $\mathrm{N}_{2}$ flow are slightly higher than those obtained under $\mathrm{CO}_{2}$ flow. This could be related with the fact that at low and middle temperatures, recondensation phenomena of volatile matter on solid would inhibit the evolution of tars in presence of $\mathrm{CO}_{2}$ [30]. Also, according to the literature [35], $\mathrm{CO}_{2}$ treatment may produce oxygen atomic bridges to form slit micropores between graphene sheets. By contrast, at the pyrolysis zone of highest temperatures, $\mathrm{k}_{\mathrm{ap}, \mathrm{Ti}}$ are clearly higher under $\mathrm{CO}_{2}$ atmosphere than those obtained under $\mathrm{N}_{2}$ flow. This could be due to the most efficient interaction between $\mathrm{CO}_{2}$ and carbon because at temperatures higher than $700^{\circ} \mathrm{C}$ Boudouart reaction is at thermodynamic regime's condition [30]. Energies associated to the pyrolysis zones of lower and higher temperatures, 200$350^{\circ} \mathrm{C}$ and $600-900^{\circ} \mathrm{C}$, respectively, were estimated by the equations 3-4 and these values are showed in Table 6. It must be note that in the middle pyrolysis zone $\left(350-600^{\circ}\right)$, $\mathrm{k}_{\mathrm{ap}, \mathrm{Ti}}$ values in Table 5 indicate that the higher the temperature the lower the $\mathrm{k}_{\mathrm{ap}, \mathrm{Ti}}$. As we indicate above in the experimental section, the conventional Arrhenius kinetic formulation cannot be employed in this middle zone and therefore equation 5 and 6 were employed to estimate the activation energies. We discuss firstly results obtained at the low and high ranges of temperatures. It can be seen from values in Table 6 that in the pyrolysis zone of low temperatures (200$300^{\circ} \mathrm{C}$ ), activation energy obtained under $\mathrm{CO}_{2}$ flow is smaller than that obtained under $\mathrm{N}_{2}$ flow $\left(12.4 \mathrm{kcal} . \mathrm{mol}^{-1}\right.$ against $16.1 \mathrm{kcal}^{\mathrm{mol}}{ }^{-1}$ ). This can be due to the fact that $\mathrm{CO}_{2}$ is an oxidizing gas that reacts with carbonaceous precursor inducing the evolution of volatiles while under inert gas as
$\mathrm{N}_{2}$, a higher energy quantity is required to induce volatile evolution reactions. By contrast, in the pyrolysis zone between $600^{\circ} \mathrm{C}$ and $900^{\circ} \mathrm{C}$, the activation energy obtained under $\mathrm{CO}_{2}$ flow is about three times higher than that obtained under $\mathrm{N}_{2}$ flow (27.8kcal.mol ${ }^{-1}$ against $8.8 \mathrm{kcal} \mathrm{mol}^{-1}$ ). This result can be explained by the fact that under $\mathrm{N}_{2}$ atmosphere the mass remaining at temperature higher than $700^{\circ} \mathrm{C}$ is practically constant (Fig. 2B). Therefore, it seems to be logical to suggest that energy requirement are lower for the activation under $\mathrm{N}_{2}$ flow by means of carbon atoms re-arrangement that can induce the formation under inert atmosphere of slit microporous as discussed above. By contrast, the energy requirements for the carbon gasification under $\mathrm{CO}_{2}$ flow are higher [32]. This result was expected because at $900^{\circ} \mathrm{C}$, the wood was fully carbonized without any evident changes in the mass remaining and therefore, the interaction between this material enrichment in carbon atoms and $\mathrm{N}_{2}$ is negligible. This discussion is reinforced by the results of micropore volume from Table 4, which show that at temperatures higher than $600^{\circ} \mathrm{C}$, the production of micropore volume in the structure of the carbons is remarkably higher under $\mathrm{CO}_{2}$ flow than that obtained under $\mathrm{N}_{2}$ flow. Finally, it is important to remark that in the pyrolysis zone of middle temperatures $\left(350-600^{\circ} \mathrm{C}\right.$ ), values of activation energies (Table 6$)$ obtained on $\mathrm{CO}_{2}$ or $\mathrm{N}_{2}$ atmospheres were very similar and both practically negligible $\left(0.09\right.$ and $\left.0.06 \mathrm{kcal}^{\mathrm{mol}} \mathrm{mol}^{-1}\right)$ which reinforce the above discussion which suggest that in this pyrolysis zone, an incipient aromatization of carbon atoms can take place independently of reaction atmosphere [1]. Regarding to frequency pre-exponential factor (A), it can be seen from values in Table $\mathbf{6}$ that in the pyrolysis zones of low and high temperatures its trends are very similar than those followed by the activation energies. Frequency factor values obtained at the pyrolysis zone $\left(350-600^{\circ} \mathrm{C}\right)$, and mainly those obtained under $\mathrm{N}_{2}$ atmosphere at the pyrolysis zone $\left(600-900^{\circ} \mathrm{C}\right)$ are clearly lower than those commonly obtained in uni- or bimolecular homogeneous gas phase reactions [28] indicating that pyrolysis of sawdust of Algarroba wood occurs in heterogeneous phase. The very low value of $\mathrm{A}$ factor obtained under $\mathrm{N}_{2}$ atmosphere $\left(3.1 \times 10^{-2} \mathrm{~min}^{-1}\right)$ in the pyrolysis zone of higher temperatures is in agreement with the above suggestion regarding to the re-arrangement of carbons layers without no representatives lost of mass (Fig. 2B). Present efforts are aimed to verify this behaviour with other kinds of carbon precursor materials and to seek evidences to confirm the three steps proposed for the pyrolysis of wood as and the influence of composition upon kinetic parameters. 


\subsection{General Discussion}

According to Bahng and co-workers [36] the pyrolysis of biomass can be described, assuming a single reaction as following Eq. (7) [37-40]:

$$
d \alpha / d t=A \cdot f(\alpha) \cdot \exp (-E / R \cdot T)
$$

The variable $\alpha$ is the degree of transformation, $\alpha=\left(\mathrm{m}_{0}-\right.$ $\mathrm{m}) /\left(\mathrm{m}_{0}-\mathrm{m}_{\infty}\right)$, where $\mathrm{m}$ is the mass of biomass and the subscripts 0 and $\infty$ refer to the initial and residual amounts, respectively. Parameters E and A are the activation energy and the pre-exponential factor and $\mathrm{R}$ is the ideal gas constant and $[f(\alpha)=1-\alpha]$, assuming a one-step first-order reaction (shown in Eq. 8).

$$
\begin{aligned}
& \mathrm{d} \alpha / \mathrm{dt}=\mathrm{A} \cdot(1-\alpha) \cdot \exp \left(-\mathrm{E} / \mathrm{RT}_{(\mathrm{t})}\right) \\
& =\mathrm{A} \cdot \exp (-\mathrm{E} / \mathrm{RT}) \cdot \exp [(-\mathrm{A} / \beta) \cdot \exp (-\mathrm{E} / \mathrm{RT}) \cdot \mathrm{dT}] \\
& \mathrm{Ln}(\beta) \approx \mathrm{C}_{1}-(\mathrm{E} / \mathrm{R} \cdot \mathrm{T})
\end{aligned}
$$

where $\beta$ corresponds to the heating rate $\mathrm{dT} / \mathrm{dt}\left(\right.$ in ${ }^{\circ} \mathrm{C} \cdot \mathrm{min}^{-1}$ ) and $\mathrm{C}_{1}$ is constant. Thus the value of activation energy, $\mathrm{E}$ can be obtained from the slope of the plot of $\operatorname{Ln}(\beta)$ as a function of reciprocal Temperature $(1 / \mathrm{T})$. The ASTM standard method [41] for determination of Arrhenius constants relies on a variant of the Ozawa method [37]. According to the standard, an experimenter has to measure a series of kinetic curves at different heating rates. In practice, for an accurate statistical manipulation, the experiment should include measurements at four or more different heating rates [36]. In practice, two experiments with two heating rates are sufficient for these calculations but an acceptable estimation of $\mathrm{E}$ is only possible in the case where these heating rates considerably differ. The present kinetic parameters were not estimated from a modulated thermo gravimetric analysis (MTGA) and because of the limitations of our equipments it was not possible to perform the present kinetic studies with heating rates considerably different one to each other. However, if the kinetic studies are performed in absence of different heating rates, $\beta$ is equal to zero and concomitantly the $\left[\exp \left[(-\mathrm{A} / \beta) \cdot \int \exp (-\mathrm{E} / \mathrm{RT}) \cdot \mathrm{dT}\right]\right.$ member in equation 8 is equal to the unit, and thus, equation 8 reduce to classical Arrhenius expression from Eq. (4). It's important to improve the technical conditions of our equipment in order to show this approximation is valid to demonstrate the reliability of the present results. In addition, the present activation energy of about $16.1 \mathrm{kcal} . \mathrm{mol}^{-1}$ (Table 6) obtained under $\mathrm{N}_{2}$ flow in the pyrolysis zone of low temperature is in good agreement with the value obtained by López-Pasquali and co-workers of about $16.7 \mathrm{kcal} . \mathrm{mol}^{-1}$ employing a constant hating rate for the carbonization of another type of Algarroba wood [42]. Finally, it should be pointed out that carbon derived materials obtained from sawdust of wood contain lower ash content that those prepared from other lignocellulosic materials such as agroindustrial bio-wastes and clearly much lower than those obtained from petroleum precursors. This is one of the reasons why activated carbon materials prepared from sawdust of wood has been employed successfully in catalytic heterogeneous reactions [1]. For example, Laine et al. [4, 5] have showed that pore volume of activated carbon supports play an important synergistic role upon the activity and selectivity of NiMo catalysts the in thiophene hydrodesulphurization. Also, our group has showed that pore size distribution clearly influence the catalytic activity of $\mathrm{Ni}$ and NiMo catalysts in the ethylene hydrogenation [2] and the kinetics of coke deposition [3]. Also, our group have showed in different works about synthesis of activated carbons by physical activation or by pyrolysis [9], and by chemical activation [10] that the pore size distribution and surface area of activated carbons remarkably affects the photoactivity of $\mathrm{TiO}_{2}$ in the photocatalytic detoxification of 4-chlorophenol. In addition, we have showed that textural properties of activated carbon clearly influence the selectivity of main intermediate products detected during the aromatic molecules as phenol and 2,4-dichlorophenoxiacetic acid [6,7] and more recently on 4-chlorophenol [43,44] and 2-propanol [45] photooxidations. In this sense, the Fig. (4) shows the influence of two carbons upon the phenol adsorption and on the photoefficiency of $\mathrm{TiO}_{2}$ in the phenol photo detoxification under $\mathrm{UV}$-irradiation was studied as a targeted application. It can be seen in Fig. (4) that any of two $\mathrm{TiO}_{2}$-AC binary materials adsorbed higher phenol (after 15min adsorption in the dark). This enhancement in phenol molecules around photoactive $\mathrm{TiO}_{2}$ enhances the photo efficiency of the semiconductor as can also be seen in Fig. (4). This enhances has been attributed to the presence of a contact interface between $\mathrm{TiO}_{2}$ and $\mathrm{AC}$ that make possible a continuous transfer of the species from the $\mathrm{AC}$ to the $\mathrm{TiO}_{2}$ surface [45].

Our present enforces are aimed to prepare hierarchically macro-meso-micro porous carbon materials to study the influence of pore size distribution on the selectivity of NiMo catalysts in hydrocracking reactions and to verify the presence of confinement effects on the selectivity of hydrocracking consequence of specific pore size an pore volume of the support such as in the case of zeolites $[46,47]$. We do believe

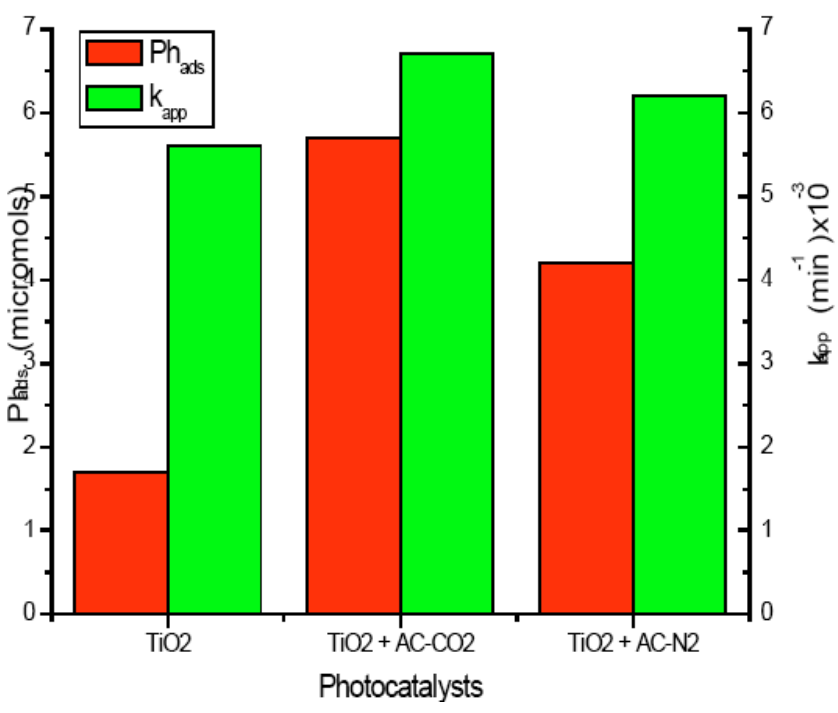

Fig. (4). Summary of kinetic results of phenol adsorption in the dark $\left(\mathrm{Ph}_{\mathrm{ads}}\right)$ and first-order apparent rate-constants $\left(\mathrm{k}_{\mathrm{app}}\right)$ of phenol photodegradation under UV-irradiation. 
that the present results regarding the pyrolysis of sawdust of a hard wood as Algarroba consists of essentially 3 different zones is a very important finding and deserve to be studied carefully. A better explanation for the present results where the reaction rates rather decreased with the increasing temperature from 350 to $600^{\circ} \mathrm{C}$ could be due to the presence of different chemical structures of the starting materials at zero holding time after heating up to the set temperatures (i.e. 350,400 and $600^{\circ} \mathrm{C}$ ). Therefore, the estimation of kinetic parameters from data of modulated thermogravimetric analysis is required to better understand the correlation of the influence of each pyrolysis zone on the pore size distribution and pore volume of carbon materials. In addition, the influence of ashes of lignocellulosic carbon precursors and the influence of additives (chemical activators) that can play the role of catalysts to improve the textural properties are necessary to clarify the significance of the present results. In this way, our groups have already reported preliminary studies regarding the influence of the pyrolysis atmosphere [48] and the effect of chemical additives [49] on the topological organization of carbon materials obtained from the controlled pyrolysis of saccharose.

\section{CONCLUSION}

The synthesis and textural characterization of carbon materials from the sawdust of Algarroba wood have been presented. First-order apparent constants $\left(\mathrm{k}_{\mathrm{ap}}\right)$ and activation energies $\left(E_{a}\right)$ estimated from the synthesis of carbon materials suggest the presence of three different pyrolysis zones. Incipient carbonization between $200-350^{\circ} \mathrm{C}$; then an extensive carbonization and re-arrangement of graphene layers between $350-600^{\circ} \mathrm{C}$, and finally the micropore formation at temperature higher than $600^{\circ} \mathrm{C}$. Phenol photodetoxification test were also performed to show the targeted application of these carbon materials. Results presented in the present work permits will permit to design and formulate potential catalysts for the selective biomass conversion as a function of the pyrolysis zone. Also, the present results showed that carbonbased photo catalysts would be able for the photooxidation of aromatic compounds.

\section{ACKNOWLEDGEMENTS}

J. Matos thanks to the Venezuelan Science and Technology Ministry for the Funds given to perform this work.

\section{NOMENCLATURE}

A

$B E T$

$E_{a}$

HJ

$\mathrm{KH}$

$\% m_{o}$

$\% m_{t}$

$\mu_{\text {porearea }}$

$\mu_{\text {porevolume }}$ $=\quad \begin{aligned} & \text { Arrhenius frequency factor, } \\ & \min ^{-1}\end{aligned}$

$=\quad$ Brunauer-Emmet-Teller method

$=$ Energy of activation, kcal.mol ${ }^{-1}$

$=\quad$ Harkins-Jura method

$=\quad$ Horvath-Kawazoe method

$=\quad$ Mass remaining at zero reaction time

$=\quad$ Mass remaining in the time $\mathrm{t}$

$=\quad$ Micropore area

$=\quad$ Micropore volume

$\begin{array}{lll}{\left[\left(\mathrm{P}_{\mathrm{n}} \mathrm{O}_{3 \mathrm{n}}\right)\right] \mathrm{n}-} & = & \text { Polyphosphate cyclic } \\ {\left[\left(\mathrm{P}_{\mathrm{n}} \mathrm{O}_{3 \mathrm{n}+1}\right)\right](\mathrm{n}+2)-} & = & \text { Polyphosphate linear } \\ t & = & \text { Reaction time } \\ T & = & \text { Temperature, }{ }^{\circ} \mathrm{C} \\ W_{\text {pore }} & = & \text { Width mean pore }\end{array}$

Subscripts

$a$

ap,Ti

kapp-phenol

o

pore

pore area

porevolume

$R$

$t$

\section{Acronyms}

$A A$

$A C$

$C_{o}$

$C_{t}$

ICP-AES

$k_{a p, T i}$

$\mathrm{k}_{\text {app-phenol }}$

\section{REFERENCES}

$=$

$=$

$=$

$=$

$=$

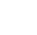

$=$ Activation

$=$ Components

$=$ Components

$=$ Zero reaction time

$=$ Component

$=$ Component

$=$ Component

$=$ Gas constant

$=$ Reaction time

$=$ Atomic absorption spectroscopy Activated carbon

Initial phenol concentration

Remaining phenol concentration:

Inductively-coupled plasma atomic emission spectrophotometer

= First-order apparent rate constant for the thermal degradation of wood

First-order apparent rateconstants for the phenol photo detoxification
[1] F. Rodríguez-Reinoso, "The role of carbon materials in heterogeneous catalysis", Carbon, vol. 36, pp.159-175, 1998.

[2] J. Matos, J. Laine, and J. L. Brito, "Activated carbon supported NiMo: effects of pretreatments and composition on catalyst reducibility and on ethylene conversion", Appl. Catal. A Gen., vol. 152, pp. 27-42, 1997.

[3] J. Matos, and J. Laine, "Ethylene conversion on activated carbon supported NiMo catalysts: effect of the Support", Appl. Catal. A: Gen., vol. 241, pp. 25-38, 2003.

[4] J. Laine, F. Severino, M. Labady, and J. Gallardo, "The synergistic participation of the support in sulfided $\mathrm{Ni}-\mathrm{Mo} / \mathrm{C}$ hydrodesulfurization catalysts", J. Catal., vol. 138, pp. 145-149, 1992.

[5] J. Laine, F. Severino, and M. Labady, "Optimum Ni composition in sulfided Ni-Mo hydrodesulfurization catalysts: effect of the support", J. Catal., vol. 147, pp. 355-357, 1994.

[6] J. Matos, J. Laine, and J.-M. Herrmann, "Synergy effect in the photocatalytic degradation of phenol on a suspended mixture of titania and activated Carbon", Appl. Catal. B Environ., vol. 18, pp. 281-291, 1998.

[7] J. Matos, J. Laine, and J.-M. Herrmann, "Effect of the type of activated carbons on the photocatalytic degradation of aqueous organic pollutants by UV-irradiated Titania”. J. Catal., vol. 200, pp. 10-20, 2001. 
[8] J. Matos, J. Laine, J.-M. Herrmann, D. Uzcategui, and J. L. Brito, "Influence of activated carbon upon titania on aqueous photocatalytic consecutive runs of phenol photomineralization", Appl. Catal. B Environ., vol. 70, pp. 461-469, 2007.

[9] T. Cordero, C. Duchamp, J.-M. Chovelon, C. Ferronato, and J. Matos, "Surface nano-aggregation and photocatalytic activity of $\mathrm{TiO}_{2}$ on H-type activated carbons", Appl. Catal. B Environ., vol. 73, pp. 227-235, 2007

[10] T. Cordero, C. Duchamp, J.-M. Chovelon, C. Ferronato, and J. Matos, "Influence of L-type activated carbons on photocatalytic activity of $\mathrm{TiO}_{2}$ in 4-chlorophenol photodegradation", J. Photochem. Photobiol. A Chem., vol. 191, pp. 122-131, 2007.

[11] A. Dufour, A. Celzard, V. Fierro, E. Martin, F. Broust, and A. Zoulalian, "Catalytic decomposition of methane over a wood char concurrently activated by a pyrolysis gas", Appl. Catal. A Gen., vol. 346, pp. 164-173, 2008 .

[12] A. Dufour, A. Celzard, B. Ouartassi, F. Broust, V. Fierro, and A. Zoulalian, "Effect of the micropores diffusion on kinetics of $\mathrm{CH}_{4}$ decomposition over a wood-derived carbon catalyst", Appl. Catal. A Gen., vol. 360, pp. 120-125, 2009.

[13] J. Matos, K. Díaz, V. García, T. C. Cordero, and J. L. Brito, "Methane transformation in presence of carbon dioxide on activated carbon supported nickel-calcium catalysts", Catal. Lett., vol. 109, pp. 163-169, 2006.

[14] K. Díaz, V. García, and J. Matos, "Activated carbon supported NiCa: influence of reaction parameters on activity and stability of catalyst on methane reformation", Fuel, vol. 86, pp. 1337-1344, 2007.

[15] C. Di Blasi, and C. Branca, "Kinetics of primary product formation from wood pyrolysis", Ind. Eng. Chem. Res., vol. 40, pp. 5547$5556,2001$.

[16] C. Di Blasi, and C. Branca, "Kinetics of the isothermal degradation of wood in the temperature range 528-708K", J. Anal. Appl. Pyrol., vol. 67, pp. 207-219, 2003.

[17] G. Várhegyi, M. J. Antal, E. Jakab, and P. Szabó, "Kinetic modeling of biomass pyrolysis", J. Anal. Appl. Pyrol., vol. 42, pp. 73-87, 1997.

[18] J. L. Banyasz, S. Li, J. Lyons-Hart, and K. H. Shafer, "Gas evolution and the mechanism of cellulose pyrolysis", Fuel, vol. 80, pp. 1757-1763, 2001

[19] M. Lopez, M. Labady, and J. Laine, "Preparation of activated carbon from wood monolith", Carbon, vol. 34, pp. 825-827, 1996

[20] J. Matos, J. Laine, J.-M. Herrmann, "Association of activated carbons of different origins with titania in the photocatalytic purification of water. Use of solar energy", Carbon, vol. 37, pp. 1870$1872,1999$.

[21] R. Lukens, "ASTM Standards Wood. Particle size distribution", ASTM International, Easton, D2862-70, 30, 1977.

[22] R. Storel, "ASTM Standards Wood: Moisture content of wood", ASTM International, Easton, D2016-74, 409, 1986.

[23] R. Storel, "ASTM Standards Wood: Ash in wood", ASTM International, Easton, D1102-84, 409, 1986.

[24] R. Storel, "ASTM Standards Wood: Analysis of wood charcoal", Easton, D1762-84, 409, 1986

[25] S. Brunauer, P. H. Emmett, and E. Teller, "Adsorption of gases in multimolecular layers", J. Am. Chem. Soc., vol. 60, pp. 309-319, 1938.

[26] W. D. Harkins, and G. Jura, "Surfaces of solids. XIII. A vapor adsorption method for the determination of the area of a solid without the assumption of a molecular area, and the areas occupied by nitrogen and other molecules on the surface of a solid", J. Am. Chem. Soc., vol. 66, pp. 1366-1373, 1944

[27] G. Horvath, and K. Kawazoe, "Methods for the calculation of effective pore size distribution in molecular sieve carbon", J. Chem. Eng. Jpn., vol. 16, pp. 470-475, 1983.

[28] K. Denbigh, "The Principles of Chemical Equilibrium", Cambridge University Press, UK, pp. 449-450, 1970.
[29] M. Sefain, S. El-Kalyoubi, and N. Shukry, "Thermal behavior of holo- and hemicellulose obtained from rice straw and bagasse", $J$. Polyme. Sci. Polym. Chem., vol. 23, pp. 1569-1577, 1985.

[30] T. Wigmans, "Industrial aspects of production and use of activated carbons", Carbon, vol. 27, pp. 13-22, 1989.

[31] J. Matos, M. Labady, A. Albornoz, J. Laine, and J. L. Brito, "Topological organization and textural changes of carbon macronetworks submitted to activation with $\mathrm{N}_{2}$ and $\mathrm{CO}_{2}{ }^{\prime}$, J. Mater. Sci., vol. 39, pp. 3705-3716, 2004.

[32] J. Laine, A. Calafat, and M. Labady, "Preparation and characterization of activated carbons from coconut shell impregnated with phosphoric acid", Carbon, vol. 27, pp. 191-195, 1989.

[33] F. E. Huggins, G. P. Huffman, N. Shah, F. W. Lytle, R. B. Greegor, and R. G. Jenkins, "In situ XAFS studies of catalyzed pyrolysis and gasification reactions of lignite", Phys. B Condensed Mater., vol. 158, pp. 178-179, 1989.

[34] S. G. Chen, and R. T. Yang, "Unified mechanism of alkali and alkaline earth catalyzed gasification reactions of carbon by $\mathrm{CO}_{2}$ and $\mathrm{H}_{2} \mathrm{O}$ ", Energy Fuels, vol. 11, pp. 421-427, 1997.

[35] F. Rodriguez, F. Ruette, and J. Laine, "Molecular modeling of micropores in activated carbon", Carbon, vol. 32, pp. 1536-1537, 1994.

[36] M. K. Bahng, C. Mukarakate, D. J. Robichaud, and M. R. Nimlos, "Current technologies for analysis of biomass thermochemical processing: a review", Anal. Chim. Acta, vol. 651, pp. 117-138, 2009.

[37] T. Ozawa, "A new method of analyzing thermogravimetric data", Bull. Chem. Soc. Jpn., vol. 38, pp. 1881-1886, 1965.

[38] V. Mamleev, S. Bourbigot, M. Le Bras, and J. Lefebvre, "Three model-Free methods for calculation of activation energy in TG", $J$. Therm. Anal. Calor., vol. 78, pp. 1009-1027, 2004.

[39] S. Hu, A. Jess, and M. H. Xu, "Kinetic study of chinese biomass slow pyrolysis: comparison of different kinetic models", Fuel, vol. 86, pp. 2778-2788, 2007.

[40] J. J. M. Orfao, F. J. A. Antunes, and J. L. Figueiredo, "Pyrolysis kinetics of lignocellulosic materials-three independent reactions model", Fuel, vol. 78, pp. 349-358, 1999.

[41] "ASTM standard test method for decomposition kinetics by thermogravimetry", ASTM International, West Conshokocken, E1641, 2007

[42] C. E. López-Pasquali, C. A. Wottitz, R. G. Martínez, and H. A Herrera, "Carbonization of Algarrobo Negro (Prosopis Nigra): a study of its microstructure and main volatile components", Latin. Amer. Appl. Res., vol. 32, pp. 321-325, 2002.

[43] J. Matos, A. García, T. Cordero, J.-M Chovelon, and C. Ferronato, "Eco-friendly $\mathrm{TiO}_{2}-\mathrm{AC}$ photocatalyst for the selective photooxidation of 4-chlorophenol", Catal. Lett., vol. 130, pp. 568-574, 2009.

[44] J. Matos, A. García, and P. S. Poon, "Environmental green chemistry applications of nanoporous carbons", J. Mater. Sci., vol. 45, pp. 4934-4944, 2010.

[45] J. Matos, E. García-López, L. Palmisano, A. García, and G. Marci, "Influence of activated carbon in $\mathrm{TiO}_{2}$ and $\mathrm{ZnO}$ mediated photoassisted degradation of 2-propanol in gas-solid regime", Appl. Catal. B Environ., vol. 99, pp. 170-180, 2010.

[46] E. Benazzi, L. Leite, N. Marchal-George, H. Toulhoat, and P. Raybaud, "New insights into parameters controlling the selectivity in hydrocracking reactions", J. Catal., vol. 217, pp. 376-387, 2003.

[47] H. Toulhoat, P. Raybaud, and E. Benazzi, "Effect of confinement on the selectivity of hydrocracking", J. Catal., vol. 221, pp. 500$509,2004$.

[48] J. Matos, and J. Laine, "A carbon macro-network from the controlled pyrolysis of sacharose", J. Mater. Sci. Lett., vol. 17, pp. 649-651, 1998

[49] J. Matos, M. Labady, A. Albornoz, J. Laine, and J. L. Brito, "Catalytic effect of $\mathrm{KOH}$ on textural changes of carbon macronetworks by physical activation", J. Mol. Catal. A Chem., vol. 228, pp. 189194, 2005. 